\title{
Agronomic and Chemical Performance of Corn Cultivars under Inoculation and Co-Inoculation with Diazotrophic
}

\section{Bacteria}

\author{
Estêvão S. L. da Cunha ${ }^{1}(\mathbb{D})$, Maicon S. N. dos Santos ${ }^{1}{ }^{\mathbb{D}}$, Jefferson F. da Silva ${ }^{1}{ }^{(\mathbb{D})}$, \\ Jéssica R. de Moraes ${ }^{1(\mathbb{D})}$, Norton M. Silveira ${ }^{1 \mathbb{D}}$, Renan de O. Ferreira ${ }^{1 \mathbb{1}}$, Victória L. de Souza ${ }^{1 \mathbb{( D}}$, \\ Lhais R. Lopes ${ }^{1 \mathbb{( D}}$, Patrick T. Lopes ${ }^{2}{ }^{\mathbb{D}}$, Alberto E. Knies ${ }^{2}{ }^{\mathbb{D}}$, Giovani L. Zabot ${ }^{1}{ }^{(\mathbb{D})}$, \\ Marcus V. Tres 1, *(D) \\ 1 Laboratory of Agroindustrial Processes Engineering (LAPE), Federal University of Santa Maria, Brazil; \\ estevao.slc@gmail.com (ESLC); maiconsergions@gmail.com (MSNS); jeffersonfagundes.jfs23@gmail.com (JFS); \\ jessica.rocha95@hotmail.com (JRM); nortonrc1@hotmail.com (NMS); renanrof@hotmail.com (ROF); \\ victoriaalumertz@gmail.com (VLS); $\quad$ lhaisrlopes@gmail.com (LRL); giovani.zabot@ufsm.br (GLZ); \\ marcus.tres@ufsm.br (MVT); \\ 2 State University of Rio Grande do Sul, Brazil; patrickthiagolopes@ gmail.com (PTL); alberto-knies@ uergs.edu.br (AEK); \\ * Correspondence: marcus.tres@ufsm.br;
}

Scopus Author ID 23096241300

Received: 23.11.2020; Revised: 14.12.2020; Accepted: 15.12.2020; Published: 17.12.2020

Abstract: The intense use of agricultural fertilizers in corn crops results in serious environmental impacts, an increase in production costs, and the reduction of the soil microbial population. An alternative to these problems is the use of microorganisms present in the soil. This study aimed to evaluate the agronomic and chemical potential of different corn cultivars under inoculation and coinoculation with diazotrophic bacteria Azospirillum brasiliense and Bradyrhizobium japonicum. A field experiment was performed in a completely randomized design in a bifactorial scheme. Factor A consisted of inoculation (use of an isolate) and co-inoculation (use of the two bacteria) and factor $\mathrm{D}$, of corn cultivars (creole and hybrid) submitted to different $\mathrm{N}$ doses (40 and $80 \mathrm{~kg} / \mathrm{ha}$ or $50 \%$ and $100 \%$ of $\mathrm{N}$ dose recommended). The grain yield was up to $11862.7 \mathrm{~kg} /$ ha for the hybrid cultivar treated with bacteria co-inoculation. The oil and protein yields were up to $31 \pm 14.9 \mathrm{~g}$ oil/ $100 \mathrm{~g}$ sample and $1.1 \pm$ $0.2 \mathrm{~g}$ protein/ $100 \mathrm{~g}$ sample. Thus, the use of inoculation and co-inoculation of diazotrophic bacteria can be applied in the management of corn production as a strategy to reduce production costs and obtain higher yields.

Keywords: agricultural production management; growth-promotion bacteria; nitrogen fertilization; soil microorganisms.

(C) 2020 by the authors. This article is an open-access article distributed under the terms and conditions of the Creative Commons Attribution (CC BY) license (https://creativecommons.org/licenses/by/4.0/).

\section{Introduction}

Maize (Zea mays L.) is characterized as the main cereal cultivated in the world and one of the most consumed foods. Besides being an important product for human and animal nutrition, corn by-products are also important sources of energy, silage, and biofuel industries [1]. Furthermore, over the years, the growth of corn cultivation in several world regions is visible. According to the Food and Agriculture Organization of the United Nations (FAO), in 2018, world corn production was approximately 1.1 billion tons, in more than 193 million hectares [2]. In this context, Brazil ranks as one of the main corn producers. It was estimated 
that, in the 2019/20 harvest, Brazilian corn production exceeds 250 million tons, in approximately 65.6 million hectares, with an average yield of $3810 \mathrm{~kg} / \mathrm{ha}$ [3].

Corn cultivation is largely limited by several factors, such as the use of pesticides and fertilizers, which directly influence the physical and biological characteristics of the soil, technological level and the adoption of agricultural machinery and implements, and the occurrence of pests and diseases in the production environment $[4,5]$. This scenario implies the necessity of alternative strategies that make it possible to compensate for the plant demand for nutrients without causing environmental and economic damages [6]. The current literature predominantly addresses natural processes, such as biological nitrogen fixation (BNF) and the use of diazotrophic bacteria, such as Azospirillum spp. and Bradyrhizobium spp., which have been successfully implemented in agricultural systems [7]. The benefits of adopting this technique influence positively a major increase in productivity, since plants absorb essential elements for their development and greater hormonal performance [8].

Combining these microorganisms has been characterized as an innovative practice involving the agricultural scenario in recent years, mainly due to the efficient exploitation of agricultural species' maximum potential in field conditions [9]. These species are closely related to the atmospheric nitrogen fixation process. As a result, they contribute to higher availability of nitrogen for plants, production of important growth hormones, such as auxins and gibberellins, and higher availability of $\mathrm{P}$ due to the promotion of root increase and higher soil exploitation [10]. With the promotion of these hormones' production, there is an increase in the process of root development, causing a higher absorption of factors such as water and nutrients [11]. Some studies have also reported expressive gains of up to $30 \%$ in corn grain yields under the inoculation of Azospirillum spp. [12,13]. Also, the co-inoculation of Azospirillum spp. and Bradyrhizobium spp. resulted in higher production and better performance of the corn yield components [14,15]. The application of growth-promoting bacteria on plants has been an excellent tool for reducing costs in many farmers' agricultural production and minimizing the environmental damage caused by the overuse of agricultural fertilizers and conventional management [16]. Finally, studies with different diazotrophic bacteria that promote corn growth should be performed to maximize production gains and encourage high efficiency in using nutrients by plants.

Thus, the objective of this study was the evaluation of agronomic and chemical characteristics of cultivars of creole and hybrid corn under inoculation and co-inoculation of Azospirillum brasiliense and Bradyrhizobium japonicum. Experimental research was also carried out to investigate the composition and quantification of chemical compounds found in corn cobs and straw.

\section{Materials and Methods}

\subsection{Plant cultivation.}

Plant cultivation was carried out in a rural property located in Passo do Sobrado, the Rio Grande do Sul State (Brazil) in the 2018-2019 agricultural harvest. The local soil was classified as Dystrophic Red Yellow Argisol [17]. A soil chemical analysis was executed and the following soil properties results were obtained: clay content $(\%)-23 ; \mathrm{pH}-5.9$; SMP index - 6.2; organic matter $(\%)-2.0 ; \mathrm{CTC}_{\mathrm{pH} 7.0}\left(\mathrm{cmol}_{\mathrm{c}} / \mathrm{L}\right)-6.9 ; \mathrm{Al}$ content $\left(\mathrm{cmol}_{\mathrm{c}} / \mathrm{L}\right)-0.2 ; \mathrm{P}$ content $(\mathrm{mg} / \mathrm{L})-20.8$; and $\mathrm{K}$ content $(\mathrm{mg} / \mathrm{L})-89.0$. The fertilization and liming interpretation and 
recommendation were established based on the 2016 guidelines for the soils of Rio Grande do Sul and Santa Catarina Brazilian States [18].

\subsection{Corn cultivars.}

The two corn cultivars used in this study were the creole and the hybrid cultivar. The creole cultivar, commonly called 'Amarelão', was purchased from the Vale do Sol Rural Workers Union, the Rio Grande do Sul State (Brazil). The hybrid cultivar, called 'Nidera 50 PRO2', was acquired from the local market, while it was chosen due to its preference by local farmers.

\subsection{Inoculation and co-inoculation.}

Two commercial liquid inoculants, one based on Azospirillum brasiliense and the other one based on Bradyrhizobium japonicum were used for the study. The first one used the product BiomaMais $\left(\right.$ Bioma $^{\circledR}$ ), with Ab-V5 and Ab-V6 strains of A. brasiliense in a dosage of $4 \mathrm{~mL} /$ $\mathrm{kg}$ corn seed. For the second one, it was used the product BiomaBrady (Bioma ${ }^{\circledR}$ ), with SEMIA 5079 nad SEMIA 5080 strains of B. japonicum in a dosage of $2 \mathrm{~mL} / \mathrm{kg}$ corn seed. The inoculation and co-inoculation processes were conducted in an inoculation system, in which the seeds were mixed with the specific inoculant and then sown.

\subsection{Experimental design.}

The field plot layout was performed using treatments with $50 \%$ of the recommended nitrogen dose based on A. brasiliense, A. brasiliense + B. japonicum, and B. japonicum. Two additional control treatments (no inoculation) were used, with $50 \%$ and $100 \%$ of the recommended nitrogen dose ( 40 and $80 \mathrm{~kg} / \mathrm{ha}$, respectively), according to the 2016 guidelines for the soils of Rio Grande do Sul and Santa Catarina Brazilian States [18].

The experiment was conducted under a completely randomized design, in a bifactorial scheme with four replications. Factor A is related to inoculation and co-inoculation with rhizobia isolates (A. brasiliense, A. brasiliense $+B$. japonicum, and B. japonicum), and factor $\mathrm{B}$ is composed of two corn cultivars (creole and hybrid) (Table 1).

Table 1. Description of the treatments evaluated in this study.

\begin{tabular}{|c|c|c|}
\hline Treatments & Factor A & Factor B \\
\hline 1 & Azospirillum brasiliense & \multirow{5}{*}{ Creole corn } \\
\hline 2 & Bradyrhizobium japonicum & \\
\hline 3 & A. brasiliense $+B$. japonicum & \\
\hline 4 & No inoculation ${ }^{1}$ & \\
\hline 5 & No inoculation ${ }^{2}$ & \\
\hline 6 & Azospirillum brasiliense & \multirow{5}{*}{ Hybrid corn } \\
\hline 7 & Bradyrhizobium japonicum & \\
\hline 8 & A. brasiliense $+B$. japonicum & \\
\hline 9 & No inoculation $^{1}$ & \\
\hline 10 & No inoculation $^{2}$ & \\
\hline
\end{tabular}

The sowing procedure was carried out manually, in 40 plots of $1.5 \mathrm{~m} \times 3.3 \mathrm{~m}$. Each plot consisted of 3 lines, with a spacing of $0.50 \mathrm{~m}$ between rows and approximately $0.33 \mathrm{~m}$ between plants, totaling approximately 35 plants per plot or 70,000 plants/ha. Corrections for $\mathrm{P}$ and $\mathrm{K}$ concentrations were made according to the 2016 guidelines for the soils of Rio Grande do Sul and Santa Catarina Brazilian States [18]. The N was applied 20\% at the base and $80 \%$ 
at the coverage, respecting the treatments. Fertilization at sowing corresponded to $20 \mathrm{~kg} / \mathrm{ha}, 90$ $\mathrm{kg} / \mathrm{ha}$, and $60 \mathrm{~kg} / \mathrm{ha}$ of $\mathrm{N}, \mathrm{P}$, and $\mathrm{K}$, respectively. The $\mathrm{N}$ fertilization (urea) was carried out in the V6 stage, according to the phenological scale proposed by Ritchie et al. (1997) [19] in a dose equivalent to $80 \mathrm{~kg} / \mathrm{ha}$ of $\mathrm{N}$. When necessary, the corn plants received phytosanitary treatments. The control of weed was carried out manually. After the corn harvest, the grains, straws, and cobs were separated, dried for $48 \mathrm{~h}$ at $70^{\circ} \mathrm{C}$, and ground in a Willey Knife Mill (SL 30, Solab, Brazil) for further analysis.

\subsection{Analyses.}

\subsubsection{Yields.}

For data collection, corn cobs located at the central sowing row of the experimental plots were used. Six plants were collected from2 linear meters of the sowing rows for each treatment. The following parameters were analyzed: number of rows per corncob, number of grains per row, 1000grain weight, and corn cob length. Also, the grains were dried to reach moisture of $13 \%$, and, after that, the grain yield $(\mathrm{kg} / \mathrm{ha})$ was estimated. All described parameters were submitted to analysis of variance. When significant differences between treatments were seen, the samples were analyzed by Tukey's test at 5\% probability of error, using the software SASM - Agri ${ }^{\circledR}$ and Sisvar ${ }^{\circledR}$.

\subsubsection{Subcritical water hydrolysis.}

To quantify reducing sugars present in corncobs and straw, the subcritical water hydrolysis $(\mathrm{SWH})$ procedure was applied. For the process, multipurpose equipment was used [20]. This equipment was equipped with a 316L stainless steel reactor (internal volume of 25 $\mathrm{mL})$, a band heater $(1500 \mathrm{~W})$ with a thermocouple for temperature measurement, a control panel programmable temperature, a liquid pump (PU-4087, Jasco, Japan), stainless steel pipelines for fluid transportation ( $3 \mathrm{~mm}$ and $1.5 \mathrm{~mm}$ outside diameter), an analog pressure gauge (50 MPa) and a micrometer valve (3125GY, Hoke, USA).

Separately, approximately $10 \mathrm{~g}$ of each biomass (corn cobs and straw), dried and ground, was inserted into the reactor vessel for each treatment. After the reactor vessel was fastened in the hydrolysis unit, distilled water (approximately $25^{\circ} \mathrm{C}$ ) was pumped at a constant flow rate $(8 \mathrm{~mL} / \mathrm{min})$. After the piping system and the reactor were filled with fluid, the micrometer valve was closed, and the pumping continued until the manometer indicated the pressure of $25 \mathrm{MPa}$, chosen according to the literature [21]. The analog pressure gauge was stopped, and the band heater was programmed to reach the desired working temperature $\left(220^{\circ} \mathrm{C}\right)$. During its gradual increase, the pressure was controlled to maintain its initial value. The total hydrolytic reaction time was 5 minutes, totalizing a volume of $40 \mathrm{~mL}$ of the hydrolyzed sample collected at the end of the process. The tests were randomized and performed in duplicates.

\subsubsection{Total reducing sugars.}

The total reducing sugars analysis was performed by the calorimetric dinitrosalicylic method (DNS) [22] using D-glucose as standard. To prepare the hydrolysate and DNS solution, $1 \mathrm{~mL}$ of both were mixed, and the mixture was heated in a water bath $\left(100^{\circ} \mathrm{C}\right)$ for 5 minutes. After, $8 \mathrm{~mL}$ of potassium sodium tartrate solution ( $15.1 \mathrm{~g}$ solute/ $\mathrm{L}$ water) was added to stabilize 
the reddish-brown coloring acquired by the heated mixture, which was cooled in a thermostatic bath with water at $25^{\circ} \mathrm{C}$. To measure the absorbance, a spectrophotometer (UV-2700, Shimadzu, Japan) was used, at a wavelength of $575 \mathrm{~nm}$. For each hydrolysate sample, the reducing sugars yield (YRS) and the efficiency (E) were calculated by equations 1 and 2, respectively:

$$
\begin{aligned}
& Y_{R S}=\left(\frac{m_{R S}}{m_{S A}}\right) \times 100 \\
& E=\left(\frac{m_{R S}}{m_{C A}}\right) \times 100
\end{aligned}
$$

Where:

mRs: mass ( $\mathrm{g}$ ) of total reducing sugars in the hydrolyzed solution;

msa: initial mass ( $\mathrm{g}$ ) of corn straws and cobs inserted in the reactor vessel at the beginning of the process;

mCA: initial mass $(\mathrm{g})$ of carbohydrates (hemicellulose + cellulose).

\subsubsection{Soxhlet extraction.}

Corn grain oil was extracted using a Soxhlet extractor (MA491/6, Marconi, Brazil) and a thermostatic bath (SL-152, Solab, Brazil). For each test, $1 \mathrm{~g}$ of sample and $200 \mathrm{~mL}$ of nHexane were used. After weighing, the samples were placed on a filter paper, folded and inserted into the apparatus's main chamber. After this process, the thermostatic bath was connected to the extractor and programmed for the working temperature $\left(-8{ }^{\circ} \mathrm{C}\right)$. After the bath reached the desired temperature, the total volume of $n$-Hexane was added to the distillation flask, which was heated by a band heater. At the end of each test, $n$-Hexane was evaporated from the flask, and the oil mass was quantified by gravimetry. The tests were randomized and performed in duplicate. The oil yield ( $\mathrm{Y}_{0}$; $\mathrm{g}$ of oil per $100 \mathrm{~g}$ of raw material) was calculated by Equation 3.

$$
\mathrm{Y}_{O}=\left(\frac{\mathrm{m}_{\mathrm{O}}}{\mathrm{m}_{\mathrm{SA}}}\right) \times 100
$$

Where:

mo: corn grain oil mass $(\mathrm{g})$;

msa: initial mass $(\mathrm{g})$ of corn grain inserted in the Soxhlet extractor's main chamber.

\subsubsection{Protein determination.}

The protein determination procedure, which includes the sulfuric acid digestion and nitrogen distillation processes, was carried out using the Kjeldahl method [23].

\subsubsection{Sulfuric acid digestion.}

The sulfuric acid digestion was performed using approximately $0.1 \mathrm{~g}$ of corn grain sample for each treatment, loaded in a sample tube. To these samples, $1.5 \mathrm{~g}$ of potassium sulfate, $0.3 \mathrm{~g}$ of copper sulfate, and $0.3 \mathrm{~mL}$ of concentrated sulfuric acid were added. Subsequently, the sample tube was positioned in the digester block, preheated to $50{ }^{\circ} \mathrm{C}$, and its temperature was gradually increased until it reached $350{ }^{\circ} \mathrm{C}$. After the solution showed a greenish color, the sample tube was left for 30 minutes in the digester block. After this process, the heating was stopped. After cooling, $20 \mathrm{~mL}$ of distilled water was added to the sample tube, stirring it until the digestion residue was completely dissolved. 


\subsubsection{2. $N$ distillation.}

For the $\mathrm{N}$ distillation procedure, $10 \mathrm{~mL}$ of a boric acid solution $\left(\mathrm{H}_{3} \mathrm{BO}_{3}\right)$ was pipetted with a color indicator in a $120 \mathrm{~mL}$ Erlenmeyer flask, which was positioned at the outlet of the distiller. After, $10 \mathrm{~mL}$ of $13 \mathrm{~N}$ sodium hydroxide solution $(\mathrm{NaOH})$ was added at the distiller entrance. Posteriorly, the distiller valve was opened gradually, and the solution was mixed with the contents of the sample tube. After the valve was closed, the distiller boiler temperature was raised until the water boiled, and the distillation occurred until the volume of the boric acid solution was twice the initial volume. Finally, the Erlenmeyer flask's content was titrated with $\mathrm{HCl} 0.07143$ until it changed from green to dark pink. The tests were randomized and performed in triplicates.

For the color indicator solution, $0.75 \mathrm{~g}$ of bromocresol green and $0.3 \mathrm{~g}$ of methyl red were dissolved in $500 \mathrm{~mL}$ of ethyl alcohol. The sodium hydroxide $(\mathrm{NaOH})$ solution $(52 \mathrm{~g}$ $\mathrm{NaOH} / 100 \mathrm{~mL}$ distilled water) was added. The boric acid solution was prepared by dissolving $40 \mathrm{~g}$ of $\mathrm{H}_{3} \mathrm{BO}_{3}$ in a recipient, adding the mixture and $20 \mathrm{~mL}$ of the color indicator solution in a $2 \mathrm{~L}$ volumetric flask, with the volume completed with distilled water. The calculation of the protein content ( $\mathrm{Y}_{\mathrm{P}}$; g of equivalent proteins per each $100 \mathrm{~g}$ of raw material) was done according to Equation 4, where the nitrogen-to-protein conversion factor (6.25) was adopted [24].

$$
\mathrm{Y}_{P}=\mathrm{N} \times 6.25
$$

Where:

$\mathrm{N}$ : total percentage of nitrogen in the sample $(\%)$.

\section{Results and Discussion}

\subsection{Yield components.}

Corn yield components, such as number of rows per cob, number of grains per cob, 1000 grain weight, and cob length were evaluated in creole and hybrid cultivars under inoculation and co-inoculation with rhizobia isolates (A. brasiliense, A. brasiliense $+B$. japonicum, and B. japonicum) (Table 2).

Table 2. Description of the treatments evaluated in this study.

\begin{tabular}{c|c|c|c|c|c} 
Treatment & $\begin{array}{c}\text { \% N recommended } \\
\text { dose }\end{array}$ & $\begin{array}{c}\text { Number of } \\
\text { rows per cob }\end{array}$ & $\begin{array}{c}\text { Number of } \\
\text { grains per row }\end{array}$ & $\mathbf{1 0 0 0}$ grain weight $(\mathbf{g})$ & $\begin{array}{c}\text { Cob length } \\
(\mathbf{c m})\end{array}$ \\
\hline $\mathbf{1}$ & 50 & $14.8^{\mathrm{a} *}$ & $32.5^{\mathrm{ab}}$ & $485.8^{\mathrm{a}}$ & $15.1^{\mathrm{a}}$ \\
\hline $\mathbf{2}$ & 50 & $14.1^{\mathrm{a}}$ & $35.3^{\mathrm{a}}$ & $487.1^{\mathrm{a}}$ & $14.6^{\mathrm{a}}$ \\
\hline $\mathbf{3}$ & 50 & $14.8^{\mathrm{a}}$ & $33.0^{\mathrm{ab}}$ & $427.1^{\mathrm{ab}}$ & $15.0^{\mathrm{a}}$ \\
\hline $\mathbf{4}$ & 100 & $14.7^{\mathrm{a}}$ & $34.3^{\mathrm{a}}$ & $459.6^{\mathrm{a}}$ & $14.1^{\mathrm{a}}$ \\
\hline $\mathbf{5}$ & 50 & $14.7^{\mathrm{a}}$ & $29.7^{\mathrm{ab}}$ & $432.5^{\mathrm{ab}}$ & $14.4^{\mathrm{a}}$ \\
\hline $\mathbf{6}$ & 50 & $11.5^{\mathrm{b}}$ & $32.8^{\mathrm{ab}}$ & $372.9^{\mathrm{ab}}$ & $16.1^{\mathrm{a}}$ \\
\hline $\mathbf{7}$ & 50 & $11.2^{\mathrm{b}}$ & $30.2^{\mathrm{ab}}$ & $369.4^{\mathrm{ab}}$ & $17.2^{\mathrm{a}}$ \\
\hline $\mathbf{8}$ & 50 & $11.7^{\mathrm{b}}$ & $30.6^{\mathrm{ab}}$ & $350.2^{\mathrm{c}}$ & $16.9^{\mathrm{a}}$ \\
\hline $\mathbf{9}$ & 100 & $11.0^{\mathrm{b}}$ & $29.1^{\mathrm{ab}}$ & $365.1^{\mathrm{ab}}$ & $17.5^{\mathrm{a}}$ \\
\hline $\mathbf{1 0}$ & 50 & $10.9^{\mathrm{b}}$ & $25.3^{\mathrm{b}}$ & $355.3^{\mathrm{c}}$ & $14.5^{\mathrm{a}}$
\end{tabular}

* Values with different superscript letters in the same column are significantly different to the level of $5 \%$ of probability $(\mathrm{p}<0.05)$.

Considering the number of rows per corn cob component, there was a significant difference $(\mathrm{p}<0.05)$ when comparing the different cultivars' treatments. Also, there was no significant difference between the different treatments applied only to the creole cultivar and the hybrid cultivar. For treatments without inoculation, there was a significant difference considering only factor B (cultivar), ignoring the applied $\mathrm{N}$ dose. Regarding the creole cultivar, 
$\mathrm{T} 1$ and $\mathrm{T} 3$ returned the highest mean values (14.8 rows per corn cob). The control treatments (without inoculation) (T4 and T5) showed similar results (14.7 rows per corn cob) even with different doses of N. Finally, for T2, the average value obtained was 14.1 rows per corncob. For the hybrid cultivar, the highest value was found for T8 (11.7 rows per corn cob). The lowest value of the variable was obtained at T10 (10.9 rows per corn cob). There was no effect of inoculation or co-inoculation considering the same cultivar, showing this component is influenced by the cultivar's genetic characteristics [25]. These results were also found in studies that showed this component was influenced by genes located on chromosomes related to the specific cultivar's choice $[25,26]$.

Regarding the number of grains per corn cob component, there was a significant difference only between T2 (35.3 grains per corn cob) and T4 (34.3 grains per corn cob), which obtained the highest results, and T10 (25.3 grains per corn cob), the lowest result. The other treatments did not differ significantly.

According to the corn cob length component, there was no significant difference between the 10 treatments. However, the highest values were observed for the treatments applied to the hybrid cultivar. The highest corn cob length values were obtained in T9 (17.5 $\mathrm{cm})$ and T7 $(17.2 \mathrm{~cm})$. Regarding the number of grains per corn cob component and cob length components, high $\mathrm{N}$ rates applied through diazotrophic bacteria or direct application result in increased chlorophyll content in maize leaves and nitrogen in the plant's reproductive parts responding positively to these concentrations [27]. Thus, high $\mathrm{N}$ concentrations promote plants' vegetative and reproductive growth, directly affecting the leaf area index and, consequently, allocating higher concentrations of photoassimilates to form yield components $[28,29]$.

Finally, for 1000 grain weight components, the highest results were observed in the creole cultivar treatments. T2 (487.1 g), T1 (485.8 g), and T4 (459.6 g), showed the highest values, which did not differ statistically. The other treatments did not differ significantly from each other. Thus, the use of isolated bacteria and treatments with recommended $\mathrm{N}$ doses was more efficient for both cultivars, which implies a higher influence of inoculation on the 1000 grain weight than factor B (cultivar). However, a study conducted involving different isolated inoculation techniques and fertilizer application showed that in a conventional inoculation system without fertilizers, it resulted in plant height gains due to a higher rate of nutrients in the leaves, increasing productivity [30]. For grain yield, the highest values were obtained for the hybrid cultivar, for all treatments (Figure 1).

The highest grain yields were found in T7 $(11862.7 \mathrm{~kg} / \mathrm{ha}), \mathrm{T} 6(11281 \mathrm{~kg} / \mathrm{ha}), \mathrm{T} 9$ (11049.7 kg/ha), and T8 (10839.7 kg/ha), which did not differ statistically. Regarding the creole cultivar, there was a higher significant difference between treatments. T2 $(7677.4 \mathrm{~kg} / \mathrm{ha})$, T1 $(7268.5 \mathrm{~kg} / \mathrm{ha}), \mathrm{T} 3(6631.2 \mathrm{~kg} / \mathrm{ha})$, and T4 $(6310 \mathrm{~kg} / \mathrm{ha})$ did not differ significantly. However, all treatments, except for T4, differed from T5, which had the lowest grain yield $(4787.1 \mathrm{~kg} / \mathrm{ha})$. According to the yield components, in higher concentrations of $\mathrm{N}$, the nitrogenase complex and the high amount of phytohormones can increase the uptake of nutrients and solar energy from the plants, transferring these compounds to the reproductive parts of the plant, which increases the specific weight of the grains [31]. Also, the supply of $\mathrm{N}$ to plants promoted by diazotrophic bacteria solubilizes important nutrients for plants, such as iron and phosphorus. It promotes the production of growth hormones, such as auxins, gibberellins, cytokinins, and ethylene [32]. These phytohormones are responsible for developing the pollen grain and the pollen tube, which positively affects the plant fertility and 
results in a better condition for capturing fundamental factors for plant development, such as nutrients and solar radiation [31].

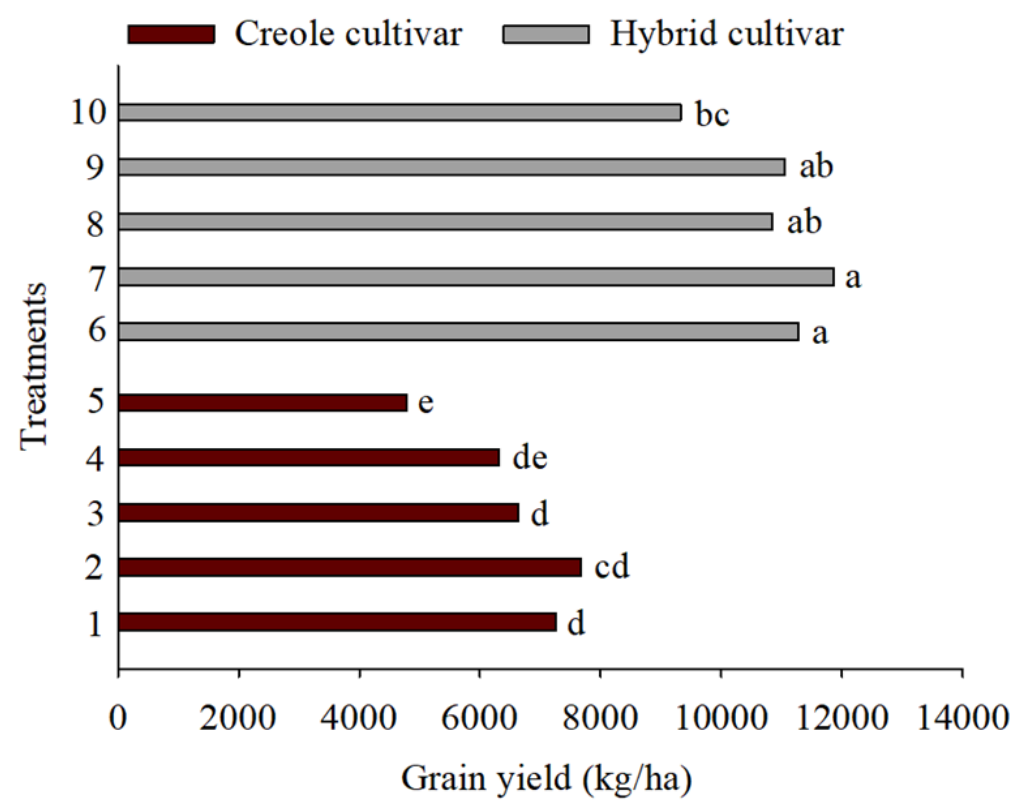

Figure 1. Grain yield (kg/ha) for the treatments evaluated in creole and hybrid corn cultivars submitted to inoculation and co-inoculation of Azospirillum brasiliense and Bradyrhizobium japonicum. Values with different superscript letters are significantly different to the level of $5 \%$ of probability $(\mathrm{p}<0.05)$.

\subsection{Total reducing sugars and efficiency.}

The YRS and E were determined by analyzing the hydrolyzed samples obtained after 5 minutes of the SWH procedure (Figure $2-$ YRS (a), E (b)).
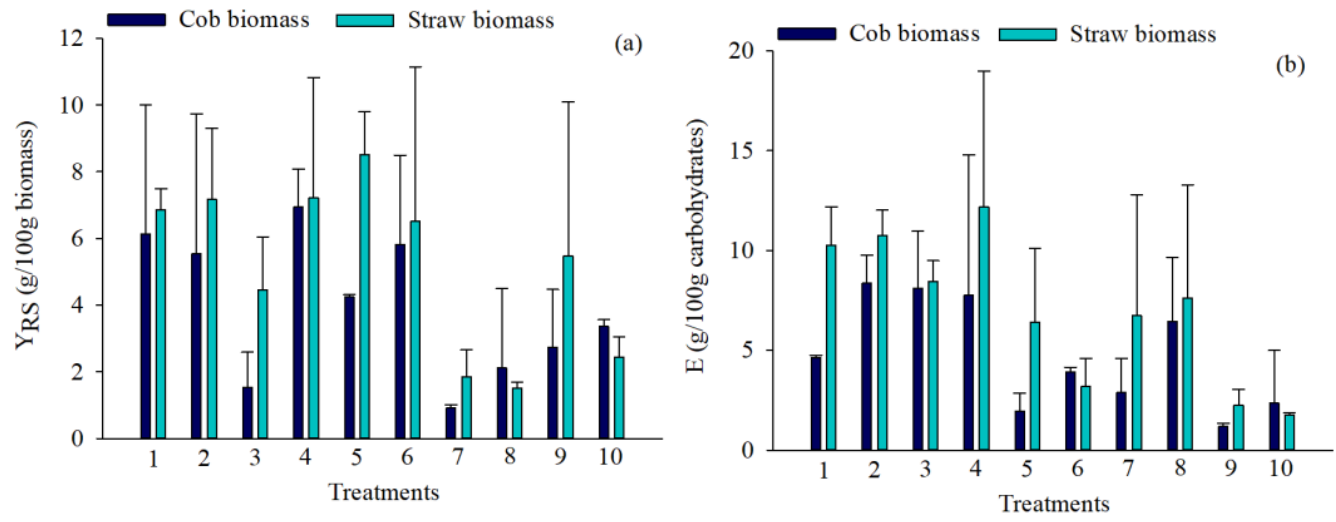

Figure 2. (a) Reducing sugars yield ( $\mathrm{Y}_{\mathrm{RS}}$ ); (b) efficiency (E) for corn cob and straw biomasses obtained from the treatments evaluated in creole and hybrid cultivars submitted to inoculation and co-inoculation of Azospirillum brasiliense and Bradyrhizobium japonicum.

According to YRs and E, there was no significant difference between treatments in this study. Comparing the treatments of the different cultivars, a similar behavior was observed. For the creole and hybrid cultivars, residual straw biomasses showed higher YRS and E values compared to cob biomass. Considering the cob biomass, the creole cultivar returned the highest results, mainly in treatments with isolated inoculation and $100 \%$ of the recommended $\mathrm{N}$ dose. It was also higher for the creole cultivar. A scenario similar to $\mathrm{Y}_{\mathrm{RS}}$ is verified. The highest values of $\mathrm{E}$ were obtained in treatments with inoculation and recommended $\mathrm{N}$ dose. However, it is important to note that in the treatment where there was inoculation, E's values were similar to the treatment with inoculation of B. japonicum and superior to the treatment with inoculation 
of $A$. brasiliense. No studies reported in the literature about obtaining reducing sugars present in a corn cob and straw biomasses under the SWH procedure. However, the use of $\mathrm{NaOH}$, as a pretreatment, applied to corn cobs promoted high $Y_{\mathrm{RS}}$ compared to other methods due to a higher digestibility of cellulose and conversion to reducing sugars [33]. The enzymatic hydrolysis procedure in a fed-batch condition also enabled high concentrations of reducing sugars [34]. At an initial concentration of $80 \mathrm{~g} / \mathrm{L}$ of biomass, after $72 \mathrm{~h}$, the hydrolytic process's efficiency was higher than $83 \%$, which shows this is a promising method to produce reducing sugars for use in ethanol production.

Regarding the corn cob biomass, for the creole cultivar, the highest YRS was obtained in T4 $(6.9 \pm 1.4 \mathrm{~g} / 100 \mathrm{~g}$ biomass $)$ and the isolated inoculation treatments $\mathrm{T} 1(6.1 \pm 3.8 \mathrm{~g} / 100 \mathrm{~g}$ biomass) and T2 $(5.5 \pm 4.1 \mathrm{~g} / 100 \mathrm{~g}$ biomass). The lowest values were obtained in T3 (1.5 \pm 1.0 $\mathrm{g} / 100 \mathrm{~g}$ biomass). For the hybrid cultivar, the highest $\mathrm{Y}_{\mathrm{RS}}$ was obtained in T6 (5.8 $\pm 2.6 \mathrm{~g} / 100$ $\mathrm{g}$ biomass). The lowest values were obtained in $\mathrm{T} 7(0.9 \pm 0.08 \mathrm{~g} / 100 \mathrm{~g}$ biomass $)$. Similar results were found for the E values, in which the creole cultivar showed higher results in relation to the hybrid.

Considering the straw biomass, for the creole cultivar, the $Y_{\mathrm{RS}}$ performance was similar in treatments, except for T3, which showed lower yields. In contrast, the hybrid cultivar showed very uneven values for $Y_{R S}$. The highest value obtained was in T6 $(6.5 \pm 4.6 \mathrm{~g} / 100 \mathrm{~g}$ biomass $)$. The lowest values were found in treatments with B. japonicum $(1.5 \pm 0.1 \mathrm{~g} / 100 \mathrm{~g}$ biomass $)$ and the co-inoculation of the two bacteria $(1.8 \pm 0.7 \mathrm{~g} / 100 \mathrm{~g}$ biomass $)$, showing a higher effect of isolated $A$. brasiliense for the production of total reducing sugars. For $\mathrm{E}$, the highest results were reached in the creole cultivar, which showed similar values. The exception was T5, which had the lowest values $(6.3 \pm 3.7 \mathrm{~g} / 100 \mathrm{~g}$ carbohydrates $)$.

\subsection{Oil yield.}

The oil content of the corn grains samples was determined by the Soxhlet extraction method, resulting in the oil yield (Figure 3).

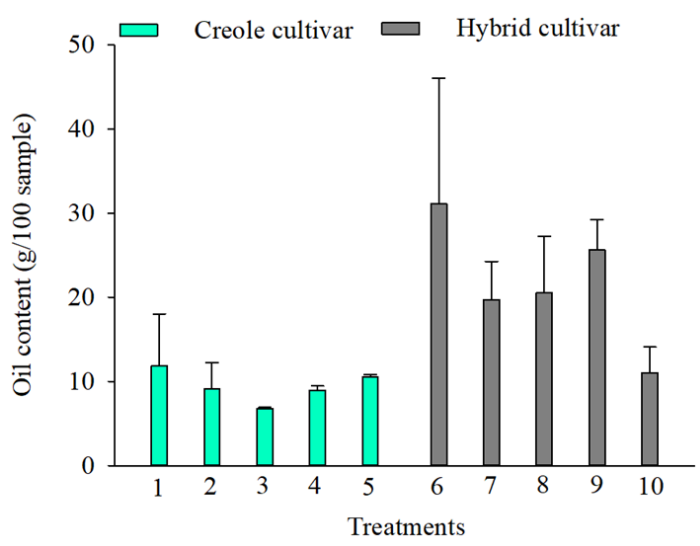

Figure 3. The oil content of the treatments evaluated in creole and hybrid corn cultivars submitted to inoculation and co-inoculation of Azospirillum brasiliense and Bradyrhizobium japonicum.

Considering the oil yield, there was no significant difference between treatments in this study. For the creole cultivar, the highest oil yield was obtained in T1 $(11.8 \pm 6.1 \mathrm{~g} / 100 \mathrm{~g}$ sample) and T5 (10.5 $\pm 0.2 \mathrm{~g} / 100 \mathrm{~g}$ sample). The lowest values were obtained in T3 (6.7 \pm 0.1 $\mathrm{g} / 100 \mathrm{~g}$ sample). For the hybrid cultivar, the higher result was obtained for treatments in which there were inoculation and co-inoculation and high $\mathrm{N}$ doses, such as T6 $(31.0 \pm 14.9 \mathrm{~g} / 100 \mathrm{~g}$ 
sample), T9 (25.6 $\pm 3.6 \mathrm{~g} / 100 \mathrm{~g}$ sample), and T8 (20.5 $\pm 3.6 \mathrm{~g} / 100 \mathrm{~g}$ sample). The lowest values were obtained in $\mathrm{T} 9(11.0 \pm 3.0 \mathrm{~g} / 100 \mathrm{~g}$ sample $)$.

Comparing the treatments of the different cultivars, the hybrid cultivar showed higher results than the creole cultivar in all treatments. For the creole cultivar, the highest result was obtained in the treatment with A. brasiliense inoculation. This scenario was similar for the hybrid cultivar, in which the best result was obtained in the same treatment. When considered inoculation with $A$. brasiliense, the increase in oil yield is directly related to grain yield since the increase in $\mathrm{N}$ concentrations is associated with the use of the bacteria [35]. Also, seed treatment with this species increases bacterial activity in plant biosynthetic processes, from higher biochemical activity production to higher photosynthetic ability [36].

\subsection{Protein yield.}

The $\mathrm{N}$ content of the corn grains samples was converted according to the nitrogen-toprotein conversion factor (6.25), resulting in the protein yield (Figure 4).

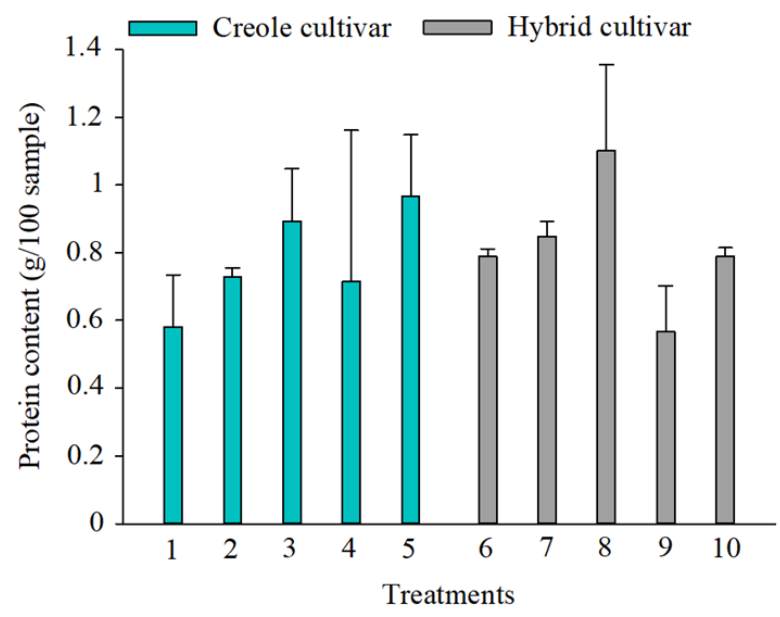

Figure 4. Protein content of the treatments evaluated in creole and hybrid corn cultivars submitted to inoculation and co-inoculation of Azospirillum brasiliense and Bradyrhizobium japonicum.

According to the protein yield, there was no significant difference between treatments in this study. For the creole cultivar, the highest protein content was obtained in T5 (0.96 \pm $0.96 \mathrm{~g} / 100 \mathrm{~g}$ sample) and T3 $(0.89 \pm 0.15 \mathrm{~g} / 100 \mathrm{~g}$ sample). The lowest values were obtained in $\mathrm{T} 1(0.58 \pm 0.58 \mathrm{~g} / 100 \mathrm{~g}$ sample $)$ and $\mathrm{T} 4(0.71 \pm 0.44 \mathrm{~g} / 100 \mathrm{~g}$ sample $)$. For the hybrid cultivar, the greatest results were obtained for treatments in which there were inoculation and coinoculation T8 $(1.1 \pm 0.25 \mathrm{~g} / 100 \mathrm{~g}$ sample $)$ and T7 $(0.84 \pm 0.04 \mathrm{~g} / 100 \mathrm{~g}$ sample $)$. The lowest values were obtained in treatments without inoculation $\mathrm{T} 9(0.56 \pm 0.13 \mathrm{~g} / 100 \mathrm{~g}$ sample) and $\mathrm{T} 10(0.78 \pm 0.02 \mathrm{~g} / 100 \mathrm{~g}$ sample $)$.

Considering the protein yield, the different cultivars' treatments showed a similar behavior (with and without inoculation). For the creole cultivar, the highest result was obtained in a no inoculation treatment and in which the $\mathrm{N}$ dose was half of that recommended. This scenario was different for the hybrid cultivar. The best results were obtained in the three treatments in which there were inoculation and co-inoculation. However, as observed for the creole cultivar, the $\mathrm{N}$ dose treatment was half of the recommended one obtained the highest values. However, some studies have found a proportional relationship between the applied $\mathrm{N}$ dose and the grains' protein content $[37,38]$. This information shows that factor B (cultivar) did not influence the protein concentration of the grains. As for the hybrid cultivar, the treatment 
with the co-inoculation of the bacteria showed superior results. This scenario may be related to grain yield since they were the treatments with the lowest grain yield. A similar result was obtained for the hybrid cultivar Pioneer 32R21 in a study that relates the yield and the protein content of the grains [39]. In this study, the cultivar Pioneer 32R21 obtained the highest protein content in a condition without application of $\mathrm{N}$ when compared to the application of $50 \mathrm{~kg} / \mathrm{ha}$. In addition, as only $50 \%$ of the recommended $\mathrm{N}$ dose was applied, this behavior can be explained by the total conversion to proteins of these treatments, which showed less vegetative growth and lower yield components (Table 2).

\section{Conclusions}

Corn is considered an agricultural species that are responsive to management by diazotrophic bacteria. The use of inoculation and co-inoculation of $A$. brasiliense and $B$. japonicum provided high gains in maize yield components. These aspects must be considered to safely define the most appropriate production management and provide the maximum expression of the components to achieve high productivities. The results present in this study contribute to contemporary agriculture since the components of corn yield were significantly higher under the inoculation and co-inoculation processes.

Also, corn cob and straw biomasses resulted in a YRS of up to $8.5 \pm 1.2 \mathrm{~g} / 100 \mathrm{~g}$ biomass and conversion efficiency rates of up to $12.1 \pm 6.8 \mathrm{~g} / 100 \mathrm{~g}$ carbohydrates the importance of the development of future studies that explore further applications. The same scenario can be described for oil and protein content. The use of isolated inoculation of the diazotrophic bacteria and the recommended $\mathrm{N}$ dose provided results of up to $31.0 \pm 14.9 \mathrm{~g}$ oil $/ 100 \mathrm{~g}$ sample, which represents very good values due to the importance of this product for various purposes.

\section{Funding}

This research was funded by Coordination for the Improvement of Higher Education Personnel (CAPES), National Council of Technological and Scientific Development (CNPq), and the Research Support Foundation of the State of Rio Grande do Sul (FAPERGS). G. L. Zabot and M. V. Tres thank CNPq for the productivity grants.

\section{Acknowledgments}

This research has no acknowledgment.

\section{Conflicts of Interest}

The authors declare no conflict of interest.

\section{References}

1. Tiammee, S.; Likasiri, C. Sustainability in corn production management: a multi-objective approach. J Clean Prod 2020, 257, 5-11, https://doi.org/10.1016/j.jclepro.2020.120855.

2. FAO. Available on: http://www.fao.org/faostat/en/\#data/QC/visualize, accessed on 11 July 2020.

3. CONAB. Available on: https://www.conab.gov.br/info-agro/safras/graos, accessed on 12 July 2020.

4. Reynolds T.W.; Waddington, S.R.; Anderson, C.L.; Chew, A.; True, Z.; Cullen, A. Environmental impacts and constraints associated with the production of major food crops in Sub-Saharan Africa and South Asia. Food Secur 2015, 7, 795-822, https://doi.org/10.1007/s12571-015-0478-1.

5. Sandhu, H.; Sciallaba, N.E.-H.; Warner, C.; Behzadnejad, F.; Keohane, K.; Houston, R.; Fujiwara, D. Evaluating the holistic costs and benefits of corn production systems in Minnesota, US. Sci Rep 2020, 10. https://doi.org/10.1038/s41598-020-60826-5. 
6. Cavalcanti, M.I.P.; Nascimento, R. de C.; Rodrigues, D.R.; Escobar, I.E.C.; Fraiz, A.C.R.; Souza, A.P. de; Freitas, A.D.S. de; Nóbrega, R.S.A.; Fernandes-Júnior, P.I. Maize growth and yield promoting endophytes isolated into a legume root nodule by a cross-over approach. Rhizosphere 2020, 15, https://doi.org/10.1016/j.rhisph.2020.100211.

7. Oliveira, I.J.; Fontes, J.R.A.; Pereira, B.F.F.; Muniz, A.W. Inoculation with Azospirillum brasiliense increases maize yield. Chem Biol Technol Agric 2018, 5, 13-15, https://doi.org/10.1186/s40538-018-0118$\mathrm{Z}$.

8. Barros, L.H.daS.; Magalhães, M.O.L.; Dalbianco, A.B.; Fidelis, R.R.; Rosa, H.H.R.; Martinez, R.A.S. Soybean inoculation techniques for the region of Tangará da Serra - MT, Brazil. Res, Soc and Dev 2020, 9. https://doi.org/10.33448/rsd-v9i8.6029.

9. Cassán, F.; Coniglio, A.; López, G.; Molina, R.; Nievas, S.; Carlan, C.L.N. de; Donadio, F.; Torres, D.; Rosas, S.; Pedrosa, F.O.; Souza, E. de; Zorita, M.D.; De-Bashan, L.; Mora, V. Everything you must know about Azospirillum and its impact on agriculture and beyond. Biol Fertil Soils 2020, 56, 461-479, https://doi.org/10.1007/s00374-020-01463-y.

10. Longhini, V.Z.; Andreotti, M.; De Souza, W.C.R.; Costa, N.R.; Filho, M.C.M.T.; Montanari, R. Nitrogen fertilization and inoculation with diazotrophic bacteria in corn intercropped with xaraés grass. Rev Bras Cienc Agrar 2017, 12, 340-347, http://dx.doi.org/10.5039/agraria.v12i3a5462.

11. Fukami, J.; Cerezini, P.; Hungria, M. Azospirillum: benefits that go far beyond biological nitrogen fixation. AMB Express 2018, 8, https://doi.org/10.1186/s13568-018-0608-1.

12. Hungria, M.; Campo, R.J.; Souza, E.M.; Pedrosa, F.O. Inoculation with selected strains of Azospirillum brasilense and A. lipoferum improves yields of maize and wheat in Brazil. Plant Soil 2010, 331, 413-425, https://doi.org/10.1007/s11104-009-0262-0.

13. Pereira, N.C.M.; Galindo, F.S.; Gazola, R.P.D.; Dupas, E.; Rosa, P.A.L.; Mortinho, E.S.; Filho, M.C.M.T. Corn yield and phosphorus use efficiency response to phosphorus rates associated with plant growth promoting bacteria. Front Env Sci Eng 2020, 8, 1-12, https://doi.org/10.3389/fenvs.2020.00040.

14. Marks, B.B.; Megías, M.; Ollero, F.J.; Nogueira, M.A.; Araujo, R.S.; Hungria, M. Maize growth promotion by inoculation with Azospirillum brasilense and metabolites of Rhizobium tropici enriched on lipochitooligosaccharides (LCOs). AMB Express 2015, 5, 1-11, https://doi.org/10.1186/s13568-015-0154-z.

15. Lucas, T.M.R.; Carlos, H.C.; Mingotte, F.L.C.; Môro, G.V. Azospirillum spp. potential for maize growth and yield. Afr J Biotechnol 2018, 17, 574-585, https://doi.org/10.5897/AJB2017.16333.

16. Santos, R.M.dos; Diaz, P.A.E; Lobo, LLB.; Rigobelo, EC. Use of plant growth-promoting rhizobacterian in maize and sugarcane:characteristics and applications. Front Sustain Food Syst 2020a, 4, https://doi.org/10.3389/fsufs.2020.00136.

17. Streck, E.V.; Kämpf, N.; Dalmolin, R.S.D.; Klamt, E.; Nascimento, P.C. do; Schneider, P.; Giasson, E.; Pinto, L.F.S. Solos do Rio Grande do Sul, $2^{\text {nd }}$ ed.: EMATER/RS-ASCAR: Porto Alegre, Brazil, 2008; pp. 222.

18. CQFS - RS/SC. Manual de adubação e de calagem para os estados do Rio Grande do Sul e de Santa Catarina. $11^{\text {th }}$ ed.: Sociedade Brasileira de Ciência do Solo: Viçosa, Brazil, 2016; pp. 376.

19. Ritchie, S.W.; Hanway, J.J.; Benson, G.O. How a corn plant develops. Ames: Iowa State University of Science and Technology. (Special Report, 48). 1997; pp. 21.

20. Abaide, E.R.; Mortari, S.R.; Ugalde, G.; Valério, A.; Amorim, S.M.; Di Luccio, M.; Moreira, R. de F.P.M.; Kuhn, R.C.; Priamo, W.L.; Tres, M.V.; Zabot, G.L.; Mazutti, M.A. Subcritical water hydrolysis of rice straw in a semi-continuous mode. J Clean Prod 2019, 209, 386-397, https://doi.org/10.1016/j.jclepro.2018.10.259 (accessed on 11 July 2020).

21. Santos, M.S.N. dos; Zabot, G.L.; Mazutti, M.A.; Ugalde, G.A.; Rezzadori, K.; Tres, M.V. Optimization of subcritical water hydrolysis of pecan wastes biomasses in a semi-continuous mode. Bioresour Technol 2020b, 306, https://doi.org/10.1016/j.biortech.2020.123129.

22. Miller, G.L. Use of dinitrosalicylic acid reagent for determination of reducing sugar. Anal Chem 1959, 31, 426-428, https://doi.org/10.1021/ac60147a030.

23. Jacobs, M.B. Micro-Kjeldahl method for biologicals. J Am Pharm Assoc 1951, 40, 151-153, https://doi.org/10.1002/jps.3030400309.

24. Villegas, E.; Ortega, B.R. Métodos químicos usados en el CIMMYT para determinar la calidad de proteína de los cereales. $1^{\text {st }}$ ed.: Centro Internacional de Mejoramiento de Mayz y Trigo: Mexico City, Mexico, 1985; pp. 29.

25. Dartora, J.; Marini, D.; Gonçalves, E.D.V.; Guimarães, V.F. Co-inoculation of Azospirillum brasilense and Herbaspirillum seropedicae in maize. Rev Bras Eng Agric Ambient 2016, 20, http://dx.doi.org/10.1590/1807-1929/agriambi.v20n6p545-550.

26. Ferreira, L.L.; Santos, G.F.; Carvalho, I.R.; Fernandes, M. de S.; Crnevale, A.B.; Lopes, K.; Prado, R.L.F.; Lautenchleger, F.; Pereira, A.I.de A.; Curvêlo, C.R. da S. Cause and effect relationships, multivariate approach for inoculation of Azospirillum brasilense in corn. Commun Plant Sci 2020, 10, https://doi.org/10.26814/cps2020006. 
27. Müller, T.M.; Sandini, I.E.; Rodrigues, J.D.; Novakowiski, J.H.; Basi, S.; Kaminski, T.H. Combination of inoculation methods of Azospirilum brasilense with broadcasting of nitrogen fertilizer increases corn yield. Cienc Rural 2015, 46, 210-215, http://dx.doi.org/10.1590/0103-8478cr20131283.

28. Singh, M.; Kumawat, N.; Tomar, I.S.; Dudwe, T.S.; Yadav, R.K.; Sahu, Y.K. Effect of gibberllic acid on growth, yield and economics of maize (Zea mays L.). J AgriSearch 2018, 5, 25-29, https://doi.org/10.21921/jas.v5i01.11128.

29. Numoto, A.Y.; Vidigal Filho, P.S.; Scapim, C.A.; Franco, A.A.N.; Ortiz, A.H.T.; Marques, O.J.; Pelloso, M.F. Agronomic performance and sweet corn quality as a function of inoculant doses (Azospirillum brasilense) and nitrogen fertilization management in summer harvest. Bragantia 2019, 78, 26-37, https://doi.org/10.1590/1678-4499.2018044.

30. Coelho, S.P.; Galvão, J.C.C.; Giehl, J.; Jesus, E.V. de; Mendonça, B.F.; Campos, S.de.A.; Brito, L.F.; Santos, T.R.dos.; Dourado, E. da R.; Kasuya, M.C.M.; Silva, M. de C.S.; Cecon, P.R. Azospirillum brasilense increases corn growth and yield in conventional low input cropping systems. Renew Agr and Food Syst 2020, 1-9, https://doi.org/10.1017/S1742170520000241.

31. Skonieski, F.R.; Viégas, J.; Martin, T.N.; Carlos Mingotti, C.A.; Naetzold, S.; Tonin, T.J.; Dotto, L.R.; Meinerz, G.R. Effect of nitrogen top dressing fertilization and inoculation of seeds with Azospirillum brasilense on corn yield and agronomic characteristics. Agron 2019, 9, 1-11, https://doi.org/10.3390/agronomy9120812.

32. Revolti, L.T.M.; Caprio, C.H.; Mingotte, F.L.C.; Moro, G.V. Azospirillum spp. potential for maize growth and yield. Afr J Biotechnol 2018, 17, 574-585, https://doi.org/10.5897/AJB2017.16333.

33. Potumarthi, R.; Baadhe, R.R.; Psipati, A.; Jetty, A. Reducing sugars production from corncobs: a comparative study of chemical and biotechnological methods. Biotechnol Appl Biochem 2014, 174, 21622170, https://doi.org/10.1007/s12010-014-1073-1.

34. Chen, M.; Zhao, J.; Xia, L. Enzymatic hydrolysis of maize straw polysaccharides for the production of reducing sugars. Carbohydr Polym 2008, 71, 411-415, https://doi.org/10.1016/j.carbpol.2007.06.011.

35. Dias, V.C.; Pelúzio, J.M.; Lima, M.D. de; Reina, E. Azospirillum brasilense and nitrogen in the yield of corn oil, in offseason cultivation, under low latitude. J Bioen Food Sci 2018, 5, 106-118.

36. Dias, V.C.; Peluzio, J.M.; Lima, M.D. de. Effects of seed inoculation with Azospirillum brasilense and nitrogen dose on oil content of corn grains. Braz J Agric 2019, 93, https://doi.org/10.37856/bja.v93i3.3264.

37. Amin, M.E.M.H. Effect of different nitrogen sources on growth, yield and quality of fodder maize (Zea mays L.). J Saudi Soc Agric Sci 2011, 10, 17-23, https://doi.org/10.1016/j.jssas.2010.06.003.

38. Zhang, L.; Liang, Z.; He, X.; Meng, Q.; Hu, Y.; Schmidhalter, U.; Zhang, W.; Zou, C.; Chen, X. Improving grain yield and protein concentration of maize (Zea mays L.) simultaneously by appropriate hybrid selection and nitrogen management. F Crop Res 2020, 249, https://doi.org/10.1016/j.fcr.2020.107754.

39. Silva, P.R.F. da; Strieder, M.L.; Coser, R.P.daS.; Rambo, L.; Sangoi, L.; Argenta, G.; Forsthofer, E.L.; Silva, A.A. da. Grain yield and kernel crude protein content increases of maize hybrids with late nitrogen sidedressing. Sci Agric 2005, 62, 487-492, http://dx.doi.org/10.1590/S0103-90162005000500014. 